\title{
African Entrepreneurs: An Analysis of their Motivation for Starting their Own Business
}

\section{B C Mitchell}

School of Economics and Management, University of Natal, Durban

\section{ABSTRACT}

This study analyses the motivation of entrepreneurs for starting a business. More specifically, it aims to identify whether entrepreneurs have common motives for starting their own business, and whether men and women have different reasons for becoming entrepreneurs. A motivation scale and openended questions were used to measure motivation on a sample of more than 100 entrepreneurs. The results of a factor analysis indicate that entrepreneurs have various reasons for starting a business, and are primarily motivated by the needs for independence, material incentives and achievement.

JEL M13

\section{INTRODUCTION}

There is tremendous attention focused on stimulating small business development in South Africa by providing financial incentives, creating infrastructure and deregulating restrictive legislation (Thomas, 1994). However, one should not lose sight of the fact that the success of a small business is also dependant on the initiative of an individual entrepreneur to create a viable business. Therefore discovering the factors that motivate the individual to embark on an entrepreneurial career becomes an important factor in stimulating entrepreneurship.

According to Harper (1991: 7) "Entrepreneurship and enterprise have been widely recognised as having a critical role to play in economic development...even more so in the poorer nations of the world". It therefore becomes evident that a greater understanding of entrepreneurs from cultures other than America and Europe is needed.

Thomas (1994) argues that a general belief exists in South Africa that the widening gap between an increasing population growth rate and a diminishing economic growth rate can be successfully reduced by fostering an economy driven by entrepreneurship. This belief is supported by a growing call from all 
sectors of the economy and society for special efforts to harness the entrepreneurial spirit of all South Africans. Maasdorp (1994) states that political and economic stability is important for transitional and post-apartheid South Africa and both depend on a sustained high rate of economic growth.

The official dismantling of Apartheid in 1990 and the establishment of a democratically elected government on the $10^{\text {th }}$ of May 1994 have resulted in unprecedented changes in the political, economic and social arenas in South Africa (Iheduru, 1998). One aspect of this change is the growing number of black entrepreneurs in various sectors of the economy from which they were previously excluded by law and social conventions. Manning and Mashigo (cited in Iheduru, 1998: 83) state that "Black entrepreneurs face certain unique constraints, such as institutional bias in favour of the larger firms, distrust of carryover apartheid-institutions, too much reliance on non-governmental organisations, and the racially exclusive character of the culture of business networks".

According to Lombard and Vosloo (1994), economic growth in South Africa is crucial. With a population growth rate of 2.7 percent for the country as a whole, at 3.9 percent in urban areas, at 3.8 percent in the economically active age groups of the population and at 4.4 percent in the age group requiring primary and secondary education, the need for strong economic growth is imperative. A commensurate economic growth rate is necessary to provide the income and tax base to finance the socio-cultural, infrastructural and other services required for human development of growing numbers of South African citizens.

The Small and Medium Enterprise (SME) sector is an important factor in achieving economic growth, development and employment. Presently, South Africa has a 45 percent unemployment rate. At the same time there are approximately 3.3 million small businesses in South Africa, employing 17 percent of the country's economically active population (Barnard, 1996). If this unemployment situation is to be addressed in a meaningful way and if South Africa wishes to have a vigorous and expanding economy, it will need a vigorous and expanding SME environment. Only a well-stimulated and structured SME sector would be in a position to create enough employment opportunities to start addressing the unemployment situation in the country (Lekota, 1995). 


\section{OBJECTIVES OF THE STUDY}

The general aim of this research is to analyse the motivational factors among African entrepreneurs in rural South Africa.

The specific aims are:

- To determine the dominant motivational factors for entrepreneurs starting their own business.

- To formulate recommendations focusing on training, development and support of entrepreneurs, especially women entrepreneurs in the region.

\section{ENTREPRENEURSHIP IN AFRICA}

\subsection{Entrepreneurship and economic growth}

Tosterud (1996) argues that the creation of economic opportunities in rural areas and villages is a necessary condition for economic growth and progress in South Africa. He states that to start a new business in a small rural town can demand substantial entrepreneurial skills and abilities, and stimulating business start-ups in villages in rural South Africa may be the biggest challenge. Furthermore, Vosloo (1994) states that Sub-Saharan Africa's deepening crisis is characterised by low investment, low productivity, weak agricultural growth, a decline in industrial output, poor export performance, climbing debt, single crop dependency, a disintegrating infrastructure and a small tax base.

\subsection{Cultural factors}

A number of authors have stressed the potential importance of socio-cultural variables in explaining variations in entrepreneurship and economic development. Wilken (1979) states that many regard entrepreneurship as one, and perhaps the most significant causal factor in the process of economic growth and development. Hence, differences in entrepreneurship among societies are believed to account for their differential rates of growth and development.

Shapero and Sokol (1982) state that the social and cultural factors that enter into the formation of entrepreneurial events are most felt through the formation of individual value systems. More specifically, in a social system that places a high value on the formation of new ventures, more individuals will choose the path of new ventures in times of transition. Entrepreneurship is then more likely to emerge under a specific set of social conditions. 
Vosloo (1994) believes that there are many misunderstandings about how market forces, privatisation and the profit motive actually operate (or fail to operate) in the African cultural context. He argues that proper regard must be given to traditional African cultural traits such as attitude towards authority, time, leisure and labour, decision-making, traditional incentives and behaviour patterns, land-use patterns, ethnic and group loyalty, family obligations, interpersonal relations, the role of women, the accumulation of wealth, individual performance and contractual bonds.

Dia (1991) argues that Western values are not always congruent with traditional incentives and behaviour patterns prevalent in most African countries. Selfreliance and self-interest tend to take a back seat to ethnicity and group loyalty. The main concern seems to be to keep social balance and equity within groups, rather than individual economic achievements. Typically, a higher value is placed on interpersonal relations and the timely execution of certain social, religious or mystic activities than on individual achievements.

In a country as socio-economically, culturally and politically heterogeneous as South Africa, the spread of the mass of entrepreneurs and their involvement in the economic process is a matter of great significance (Thomas, 1994). Thomas (1994) believes that there are two closely related questions that are important in the present phase of South Africa's socio-political transition. These are:

- How can black entrepreneurs play a greater role in the stimulation of economic development?

- How can the quantity and quality of black entrepreneurship be enhanced?

He believes that these two challenges can be interpreted in the narrow sense of African entrepreneurship, where Africans constitute about three quarters of the South African population, or more broadly as entrepreneurship amongst blacks. It is no surprise that the dilemma of entrepreneurial development in South Africa is often presented as essentially the challenge of African entrepreneurial mobilisation and development. This challenge is further accentuated by the current dilemma of vast unemployment in the country, with Africans bearing the brunt of the burden. Where self-employment is generally viewed as an important avenue towards employment, and where entrepreneurship is seen as a critical factor for the success of self-employment efforts, the mobilisation of African entrepreneurship becomes even more critical (Thomas, 1994). 


\subsection{Motivation amongst entrepreneurs}

Kuratko and Hodgetts (1995) believe that examining why people start businesses and how they differ from those who do not, may be useful in understanding the motivation that entrepreneurs exhibit during start up, as a link to the sustained behaviour exhibited later. The decision to become an entrepreneur is the result of the interaction of several factors. Veciana (1999) states that empirical studies support the fact that the need for independence, need for achievement and being "marginalised" are the dominant motivators for entrepreneurs.

Dubini (1988) examined motivation to start a business in different environmental settings in Italy, using a sample of 163 entrepreneurs. He sought to find out whether entrepreneurs have different motivations for starting a business, and whether dissatisfaction with a previous job or perception of lack of opportunities would cause someone to start a business. He asked whether "positive" motivators, such as the willingness to develop an idea and to prove oneself able to start a business, are the main reasons? His results showed that the dominant motivation factors are: a sense of individual achievement, contributions to the welfare of a group, recognition from others, material incentives, work flexibility and identification with role models.

\subsection{Cross-cultural studies}

Shane, Kolvereid and Westhead (1991) attempted to present evidence that reasons for start-ups are not the same across countries and gender, and they studied male and female entrepreneurs from Great Britain, Norway and New Zealand. The literature shows that "displacing events" were not important reasons for start-up in Japan compared with the United States. It is also suggested that in Japan the web of friendship obligation is a critical reason for start-up in business. Their study also suggests the greater importance of social status and the lesser importance of family tradition. There is also evidence that job dissatisfaction does not motivate new business formation in all countries. Although it has been found that job dissatisfaction motivates new business formation in the United States, in New Zealand venture initiators were significantly more satisfied than their American counterparts.

The work by Scheinberg and MacMillan (1988) on new business formations in 11 countries yielded six reasons why people start businesses. These include the need for approval, the perceived instrumentality of wealth, the degree of communitarianism, the need for personal development, the need for independence, and the need for escape. These results suggest that entrepreneurs in different countries appear to be motivated by different forces. The United 
States scored highest in need for independence and had no belief at all in communitarianism as a factor in the reason for start-up. In contrast to the United States, Italy's factor scores indicate that the need for independence is not an important reason for start-up. Neither is their need to escape. In fact, for Italian entrepreneurs, the only factor that is a significant reason for start-up is communitarianism. As expected, China scored highest on the need for approval and indicated a strong interest in communitarianism. Portuguese entrepreneurs feel that communitarianism is important, and similarly to their Chinese counterparts, have a very strong need for approval. In Australia, Great Britain and the United States entrepreneurs showed a strong inclination for seeing "money as means" as a reason for start-up, while the Scandinavians are significantly less motivated by this factor.

\subsection{Summary of entrepreneurial motivation studies}

Table 1 Summary of entrepreneurial motivation factors

\begin{tabular}{|c|c|c|}
\hline Researcher & $\begin{array}{c}\text { Sample } \\
\end{array}$ & $\begin{array}{l}\text { Findings } \\
\end{array}$ \\
\hline $\begin{array}{l}\text { Scheinberg \& } \\
\text { MacMillan } \\
\text { (1988) }\end{array}$ & $\begin{array}{l}1402 \text { entrepreneurs } \\
\text { from } 11 \text { countries }\end{array}$ & $\begin{array}{ll}\text { - } & \text { Need for approval } \\
\text { - } & \text { Perceived instrumentality of } \\
\text { - } & \text { Communith } \\
\text { - } & \text { Need for personal development } \\
\text { - } & \text { Need for independence; Need to } \\
\text { escape }\end{array}$ \\
\hline $\begin{array}{l}\text { Hisrich \& } \\
\text { Brush (1984) }\end{array}$ & $\begin{array}{l}\text { - } 468 \text { women entrepre- } \\
\text { neurs in the United } \\
\text { States }\end{array}$ & 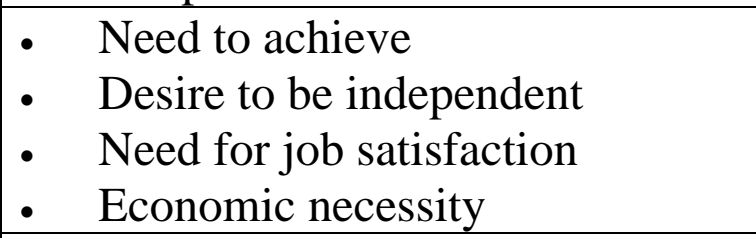 \\
\hline $\begin{array}{l}\text { Kuiper } \\
\text { (1993) }\end{array}$ & $\begin{array}{l}\text { Burkina Faso, South } \\
\text { Africa, Kenya, Mali, } \\
\text { Nigeria. }\end{array}$ & $\begin{array}{ll}\text { - } & \text { Family circumstances } \\
\text { - } & \text { Economic pressure displacement } \\
\text { - } & \text { Improve economic situation }\end{array}$ \\
\hline $\begin{array}{l}\text { Singh } \\
\text { (1993) }\end{array}$ & $\begin{array}{l}200 \text { women entrepre- } \\
\text { neurs in Delhi, India }\end{array}$ & $\begin{array}{ll} & \text { To become independent } \\
\text { - } & \text { To prove oneself; to earn money } \\
\text { - } & \text { Job satisfaction; to gain status }\end{array}$ \\
\hline $\begin{array}{l}\text { Cromie } \\
(1987)\end{array}$ & $\begin{array}{l}\text { - } 69 \text { men and women } \\
\text { entrepreneurs in } \\
\text { Belfast, Northern } \\
\text { Ireland }\end{array}$ & $\begin{array}{l}\text { - } \text { Autonomy; achievement } \\
\text { - } \text { Job dissatisfaction; money } \\
\text { - } \quad \text { Child-rearing }\end{array}$ \\
\hline
\end{tabular}


Table 1 continued

\begin{tabular}{|c|c|c|}
\hline Researcher & Sample & $\begin{array}{l}\text { Findings } \\
\end{array}$ \\
\hline $\begin{array}{l}\text { Vijaya \& } \\
\text { Kamalana- } \\
\text { bhan (1998) }\end{array}$ & $\begin{array}{l}195 \text { potential women } \\
\text { entrepreneurs in } \\
\text { Madras, India }\end{array}$ & 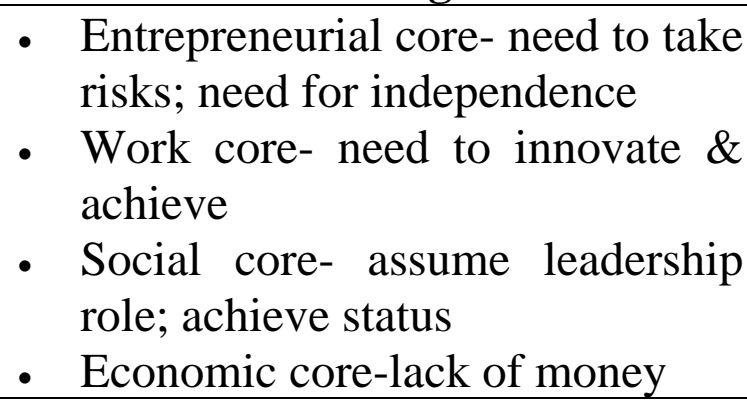 \\
\hline $\begin{array}{l}\text { Dubini } \\
(1988)\end{array}$ & $\begin{array}{l}\text { - } 163 \text { entrepreneurs } \\
\text { - } \text { from north, central \& } \\
\text { southern Italy }\end{array}$ & $\begin{array}{ll}\text { - } & \text { Achievement } \\
\text { - } & \text { Philanthropy (personal } \\
\text { contribution) } \\
\text { - Status; materialism; escape / } \\
\text { freedom } \\
\text { - } \text { Role model }\end{array}$ \\
\hline $\begin{array}{l}\text { Shane et al } \\
\text { (1991) }\end{array}$ & $\begin{array}{l}697 \text { entrepreneurs } \\
\text { from UK, Norway \& } \\
\text { New Zealand }\end{array}$ & $\begin{array}{ll}\text { - } & \text { Independence } \\
\text { - } & \text { Recognition (status) } \\
\text { - } & \text { Learning; roles } \\
\end{array}$ \\
\hline $\begin{array}{l}\text { Buttner \& } \\
\text { Moore (1997) }\end{array}$ & $\begin{array}{l}\text { - } 129 \text { women entrepre- } \\
\text { neurs in United } \\
\text { States }\end{array}$ & $\begin{array}{l}\text { - Seeking challenge } \\
\text { - Opportunity for self- } \\
\text { determination } \\
\text { - Opportunity to test skills \& } \\
\text { experience } \\
\text { - } \begin{array}{l}\text { Freedom to determine their } \\
\text { destiny }\end{array} \\
\end{array}$ \\
\hline $\begin{array}{l}\text { Goffee \& } \\
\text { Scase (1985) }\end{array}$ & $\begin{array}{l}54 \text { women entrepre- } \\
\text { neurs in United } \\
\text { Kingdom }\end{array}$ & $\begin{array}{l}\text { - } \begin{array}{l}\text { Job dissatisfaction } \\
\text { - }\end{array} \\
\text { oompatibility with other } \\
\text { obligations } \\
\text { - Economic \& social independence }\end{array}$ \\
\hline
\end{tabular}

Based on an extensive literature review, Table 1 illustrates the research findings of various authors. As can be seen from the table, the most common motivation factors evident in entrepreneurs are the need for independence, the need for achievement, the need for money, the need to escape a negative situation, the need to provide for the family, and the need to contribute to the community.

Although a number of factors have been illustrated, this study will focus on four major motivation factors that have been identified in the literature. 
Thus the study will test the following hypotheses:

$\mathrm{H}_{1} \quad$ The need for independence will be a motivating factor for entrepreneurs.

$\mathrm{H}_{2}$ The need for material incentives will be a motivating factor for entrepreneurs.

$\mathrm{H}_{3} \quad$ The need to escape a negative situation will be a motivating factor for entrepreneurs.

$\mathrm{H}_{4}$ The need to contribute to the community will be a motivating factor for entrepreneurs.

\section{RESEARCH METHODOLOGY}

The measuring instruments used in this study included a demographic questionnaire, a quantitative instrument measuring entrepreneurial motivation, and an interview guide. The demographic questionnaire was the result of an indepth literature review of what demographic factors influence entrepreneurship. The questionnaire was based on ideas from Buttner and Moore (1997), Hisrich (1986), Hisrich and Brush (1985), Fischer, Reuber and Dyke (1993), Scheinberg and MacMillan (1988), and Singh (1993). Although demographic factors such as age, marital status, education and number of children cannot be manipulated to stimulate entrepreneurship, researchers (Buttner \& Moore, 1997; Hisrich \& Brush, 1985) indicate that these factors play a role in the decision to become an entrepreneur. The items chosen for the questionnaire were based on demographic factors that have been shown in research to have an influence on entrepreneurship.

The motivation scale (Scheinberg \& MacMillan, 1988) was used to measure the motivation of entrepreneurs. The motivation scale was developed in collaboration with researchers from 11 countries, and was designed in accordance with motivation theory, which includes the influence of the theories of Vroom, McClelland, Herzberg and Maslow, in an attempt to understand which factors influence individuals to start a businesses. Although Hofstede (1980) believed that motivation theories designed in America were not always transferable to other cultures, Scheinberg and MacMillan (1988) attempted to design a motivation scale that could be used in a variety of cultures. The motivation scale is a self-reporting questionnaire consisting of 21 items. Each item contains five choices. For each statement, subjects need to choose from a five-point Likert scale. The scale include the choices 1 (no importance), 2 (little importance), 3 (moderate importance), 4 (very important), 5 (utmost importance). 


\subsection{Sample}

The empirical study was aimed at entrepreneurs who had been given loans by the Get Ahead Financial Services (GAFS). The GAFS is a non-government organisation (NGO) established to work towards the alleviation of unemployment and poverty in the black population in the rural areas of South Africa. The population from which the sample was drawn consisted of 690 entrepreneurs, representing the total number of entrepreneurs who are supported by the GAFS in the Northern Province. For the purposes of the empirical study, stratified random sampling was used, where the population was categorised according to gender. Then within each stratum (males \& females), random sampling using interval sampling was conducted. The major advantage of stratified sampling is that by preserving proportions, even of very small samples, any small minorities will be well represented (Babbie, 1998).

\subsection{Data collection}

The demographic questionnaire was essentially self-scoring. The items were printed on the answer sheet that was provided to the respondent. Due to potential difficulties with the English language, and reading and writing deficiencies of respondents, it was decided that the interviewer would ask the questions and fill in the responses of the interviewee. This procedure was followed for all of the respondents. Interviewers were trained by the researcher by means of role-playing the administration of the questionnaire. A pre-test was conducted, where the interviewers administered the questionnaire to a number of respondents. The interviewers rehearsed in asking the questions, and filling in the responses. The respondent was provided with a series of 21 self-completion questions on various motivation factors for starting his/her own business. The respondent was then requested to indicate the alternative that best expressed the extent to which the statements were applicable to him/herself. The interviewer stated the motivation factors and the alternative choices, and then filled in the interviewee's responses.

\subsection{Data analysis}

The following procedures were used to analyse the data. Firstly, frequency analyses of the demographic information were performed. Secondly, a chisquare $\left(\chi^{2}\right)$ test was performed on the data to see if there were any significant differences between male and female entrepreneurs. Thirdly, the motivation scale was analysed using a t-test to look for significant differences between the means of the female and male entrepreneurs. Fourthly, an exploratory factor analysis was performed on the motivation scale of 21 items in order to determine whether or not a stable and reliable set of entrepreneurial motivation 
factors existed. This paper will only report on the results of the factor analysis of the motivation scale.

\subsection{Results}

\subsubsection{Factor analysis of the motivation scale}

Findings from the factor analysis illustrated in Table 2 indicate the emergence of a six - factor solution that accounts for 55.67 percent of the variance.

Table 2 Rotated factor structure for motivation factors

\begin{tabular}{|l|c|}
\hline Factors & Factor loading \\
\hline Factor 1: External approval \& communitarianism & \\
\hline Welfare of ethnic group & 0.797 \\
\hline Welfare of community I live in & 0.708 \\
\hline Be respected by friends & 0.685 \\
\hline Achieve something and get recognition & 0.657 \\
\hline Welfare of relatives & 0.565 \\
\hline Desire to have earnings & 0.361 \\
\hline Factor 2: Personal development & \\
\hline Develop idea for product / business & 0.764 \\
\hline To keep learning & 0.758 \\
\hline $\begin{array}{l}\text { To be innovative and in the forefront of new } \\
\text { technology }\end{array}$ & 0.671 \\
\hline Needed more money to survive & 0.417 \\
\hline Factor 3: Recognition & \\
\hline Increase status of family & 0.765 \\
\hline Access to indirect benefits & 0.659 \\
\hline Achieve position in society & 0.442 \\
\hline Factor 4: Need for independence & \\
\hline Not to work for an unreasonable boss & 0.756 \\
\hline Have greater flexibility for private life & 0.581 \\
\hline Control my own time & 0.573 \\
\hline Factor 5: Influence company/community & \\
\hline Have more influence in community & 0.779 \\
\hline Freedom to adapt my own approach to work & 0.552 \\
\hline Factor 6: Benefits and security & 0.590 \\
\hline Frustrated in previous job & 0.587 \\
\hline Direct contribution to success of company & 0.562 \\
\hline Give self and family security & \\
\hline Extration Method: Princal Component Anasis & \\
\hline
\end{tabular}

Extraction Method: Principal Component Analysis 
This table is based on Varimax Factor Rotation

6 factors extracted / only items that loaded with absolute values greater than 0.35 are shown

The six factors identified through factor analysis are:

Factor 1: External approval and communitarianism (welfare of ethnic group, welfare of community I live in, be respected by friends, achieve something and get recognition, welfare of relatives, desire to have earnings).

Factor 2: Personal development (develop idea for product/business, to keep learning, to be innovative and in the forefront of new technology, needed more money).

Factor 3: Recognition (status of family, access to indirect benefits, achieve position in society).

Factor 4: $\quad$ Need for Independence (not to work for an unreasonable boss, have greater flexibility for private life, control my own time).

Factor 5: Influence company/community (have more influence in community freedom to adapt my own approach to work).

Factor 6: Benefits and security (frustrated in previous job, direct contribution to success of company, give self and family security).

The initial-components factor analysis method was used to determine the number of possible factors present. From the eigenvalues greater than one, it was decided to have six factors because the seventh and eight factor had eigenvalues very close to $1(1.07 \& 1.01)$. In order to determine a finer selection of factors, an orthogonal varimax rotation was performed. The factor loadings for each of the eight factors is greater than 0.35. All the eigenvalues for the respective factors are greater than 1.0, which fulfils the Kaiser criterion (SPSS, 1990 \&; 1999). A scree test was also done to confirm how many factors to select. Based on the scree plot and the Kaiser criterion, it was decided that 6 factors were the correct number of factors to extract. 
Table 3 Factors, eigenvalues, percent of variance and cumulative percent of variance

\begin{tabular}{|l|c|c|c|}
\hline \multicolumn{1}{|c|}{ Factor } & Eigenvalue & $\begin{array}{c}\text { Percent of } \\
\text { variance }\end{array}$ & $\begin{array}{c}\text { Cumulative } \\
\text { percent of } \\
\text { variance }\end{array}$ \\
\hline $\begin{array}{l}\text { External “approval” \& } \\
\text { communitarianism }\end{array}$ & 3.40 & 16.186 & 16.186 \\
\hline Personal development & 2.52 & 11.986 & 28.172 \\
\hline Recognition & 2.01 & 9.559 & 37.731 \\
\hline Need for independence & 1.43 & 6.816 & 44.547 \\
\hline Influence community & 1.19 & 5.672 & 50.219 \\
\hline Benefits and security & 1.15 & 5.451 & 55.670 \\
\hline
\end{tabular}

The six factors and their relative contribution to variance are presented in Table 3. It can be seen that all the six factors have an eigenvalue of above 1, ranging from 1.5 to 3.40. Factor 1, external approval and communitarianism, contributes a variance of 16.86 percent, followed by factor 2, personal development, which contributes 11.86 percent. Recognition, factor 3, contributes 9.559 percent of the variance, while factor 4, need for independence, explains another 6.816 percent, and factor 6, benefits and security, contributes 5.451 percent of the variance. The total cumulative variance explained by the six factors is 55.67 percent (Table 3).

The data collected was subjected to item analysis. The Cronbach's alpha coefficient $(\alpha)$ was calculated to find out the internal consistency of the items on the scale. The alpha $(\alpha)$ value for the entire motivation scale was found to be $0, .055$, which indicated that internal consistency was quite high. Cronbach's Alpha Coefficients for each factor of the scale were as follows: Factor $1=$ 0.7548 ; Factor $2=0.6357$; Factor $3=0.4988$; Factor $4=0.5134$; Factor $5=$ 0.4081 ; Factor $6=0.2199$ (see Table 4).

The complete rotated factor matrix is shown in Table 4, which also shows specific factor eigenvalues, alpha coefficients, and the percentage of total variance that each factor accounts for. As can be seen from the table, a number of items loaded onto more than one factor. For the purposes of interpretation, only factors loadings greater than 0.30 have been shown in Table 4 , and the highest loading of each variable has been identified and used in the labelling of the factors. 
Table 4 Rotated factor matrix for motivation factors

\begin{tabular}{|c|c|c|c|c|c|c|}
\hline Item & $\begin{array}{c}\text { External } \\
\text { appr. \& } \\
\text { communi- } \\
\text { tarianism } \\
\end{array}$ & $\begin{array}{l}\text { Personal } \\
\text { develop- } \\
\text { ment }\end{array}$ & $\begin{array}{l}\text { Recog- } \\
\text { nition }\end{array}$ & $\begin{array}{c}\text { Need for } \\
\text { indepen- } \\
\text { dence }\end{array}$ & $\begin{array}{c}\text { Influence } \\
\text { commu- } \\
\text { nity }\end{array}$ & $\begin{array}{l}\text { Benefits \& } \\
\text { security }\end{array}$ \\
\hline Welfare of ethnic group & 0.797 & & & & & \\
\hline $\begin{array}{l}\text { Welfare of community I } \\
\text { live in }\end{array}$ & 0.708 & & & & & \\
\hline Be respected by friends & 0.685 & & & & & \\
\hline $\begin{array}{l}\text { Achieve something and } \\
\text { get recognition }\end{array}$ & 0.657 & & & & & \\
\hline Welfare of relatives & 0.565 & & & & & \\
\hline Desire to have earnings & 0.361 & & 0.338 & & & \\
\hline $\begin{array}{l}\text { Develop idea for product/ } \\
\text { business }\end{array}$ & & 0.764 & & & & \\
\hline To keep learning & & 0.758 & & & & \\
\hline $\begin{array}{l}\text { To be innov. \& in the } \\
\text { forefront of new tech. }\end{array}$ & & 0.671 & & & & \\
\hline $\begin{array}{l}\text { Needed more money to } \\
\text { survive }\end{array}$ & & 0.417 & & & $-0,310$ & \\
\hline Increase status of family & & & 0.765 & & & \\
\hline $\begin{array}{l}\text { Access to indirect } \\
\text { benefits }\end{array}$ & & & 0.659 & 0.306 & & \\
\hline $\begin{array}{l}\text { Achieve position in } \\
\text { society }\end{array}$ & 0.441 & & 0.442 & & & \\
\hline $\begin{array}{l}\text { Not to work for an } \\
\text { unreasonable boss }\end{array}$ & & & & 0.756 & & \\
\hline $\begin{array}{l}\text { Have greater flexibility } \\
\text { for private life }\end{array}$ & & & & 0.581 & & \\
\hline Control of my own time & & & & 0.573 & 0.381 & \\
\hline $\begin{array}{l}\text { Have more influence in } \\
\text { community }\end{array}$ & 0.377 & & & & 0.779 & \\
\hline $\begin{array}{l}\text { Freedom to adapt my } \\
\text { own approach to work }\end{array}$ & & & & & 0.552 & 0.342 \\
\hline Frustrated in previous job & & & & & & 0.590 \\
\hline $\begin{array}{l}\text { Direct contribution to } \\
\text { success of company }\end{array}$ & & & & & & 0.587 \\
\hline $\begin{array}{l}\text { Give self and family } \\
\text { security }\end{array}$ & & & & & & 0.562 \\
\hline Eigenvalue & 3.40 & 2.52 & 2.01 & 1.43 & 1.19 & 1.15 \\
\hline $\begin{array}{l}\text { Cronbach’s Alpha } \\
\text { coefficient }(\alpha) \text { (overall } \\
0,7055)\end{array}$ & 0.7548 & 0.6357 & 0.4988 & 0.5134 & 0.4081 & 0.2199 \\
\hline $\begin{array}{l}\text { Percent of variance } \\
\text { explained (total 55.67\%) }\end{array}$ & 16.186 & 11.986 & 9.559 & 6,816 & 5.672 & 5.451 \\
\hline
\end{tabular}

Extraction Method: Principal Component Analysis. 
Rotation Method: Varimax with Kaiser Normalisation.

\subsubsection{Discussion of factors}

Factor 1: External approval and communitarianism

This factor had six item loadings ranging from 0.797 to 0.361 . This factor included items such as "welfare of ethnic group", "welfare of community I live in", "welfare of relatives", "be respected by friends", "achieve something and get recognition", and "desire to have earnings." All the items loaded only onto this one factor, with the exception of the item "desire to have earnings", which also loaded onto factor 3. Earnings are a way of getting approval as well as being recognised and gaining respect of others. Perhaps people felt that they needed to get earnings to gain approval and recognition.

Referring to the results of Scheinberg and MacMillan's (1988) study, this factor is a combination of factor 3 (communitarianism) and factor 1 (need for approval). Therefore the subjects seem to be motivated by a sense of community as well as being recognised for it by others. Both of these motivation factors are related to being accepted by others in the group or community.

\section{Factor 2: Personal development}

This factor had four loadings ranging from 0.764 to 0.417 . It included items such as "to keep learning", "to be innovative", "develop ideas for business" and "needed more money to survive". The item "needed more money to survive" also loaded onto factor 5, "influence community." This motivation factor represents the individual's strong need for personal achievement and ongoing learning. This factor relates to the motivation to grow and develop as a person, learning new skills and ideas, which can be used in the future.

This factor corresponds with Scheinberg and MacMillan's factor 4, namely "need for personal development." This refers to the motivation of the entrepreneur to achieve something worthwhile in his/her life, and the belief that this can be done by means of owning one's own business.

\section{Factor 3: Recognition}

This factor included item loadings ranging from 0.765 to 0.442 . Items included "increase status of family", "access to indirect benefits", and "achieve position in society." The items "access to indirect benefits" and "achieve position in society", also loaded onto other factors. The entrepreneurs are motivated by the need for bettering the situation of their families, as well as gaining more status. They believe that by going into entrepreneurship, they will get indirect benefits plus have a higher standing or position in society. 
This is similar to factor 1 of Scheinberg and MacMillan's (1988) study and revolves around the person getting respect and acknowledgement. This factor acknowledges the strong motivation force of getting others' respect and approval. People are motivated by the desire to get other people to see them in "a better light" and to gain their respect. They are concerned about what others think of them, and how they are seen in society.

\section{Factor 4: $\quad$ Need for independence}

This factor had item loadings from 0.756 to 0.573 . Items included "not to work for an unreasonable boss", "have greater flexibility for private life", and "control of my own time." The item "control of my own time", also loaded onto factor 5. This factor corresponds with the need to get away from a present situation or job, and have greater control of one's future and career. It also relates to the motivation for flexibility in one's life, and it is argued that by being one's own boss, one has more flexibility in one's lifestyle.

This factor directly related to factor 5 of Scheinberg and MacMillan's (1988) study that stresses the personal need for controlling the self. This relates to the need for having control over one's destiny and also one's quality of life.

\section{Factor 5: Influence community}

This factor had item loadings from 0.779 to 0.552 and includes items "have more influence in community" and "freedom to adapt my own approach to work." Both items also loaded onto another factor. This is related to people wanting to have a say in contributing to their own communities, and they argue that having their own business, will allow this to happen. Also, they are motivated by the desire to have their own unique approach to work, and expressing themselves through their business.

This factor is not directly related to a factor of Scheinberg and MacMillan's study.

\section{Factor 6: $\quad$ Benefits and security}

This factor had item loadings ranging from 0.590 to 0.562 and includes the following items: "frustrated in previous job", "direct contribution to success of company", and "give self and family security." This factor involves getting away from a job that they do not enjoy, and being able to make a difference. This factor relates to the belief that they are motivated by the need to be able to contribute to the success of the business, and not just be one of many employees. This factor also relates to the issue of giving their family security, which relates to knowing that your family is taken care of, and that there is job security in the future. 
This factor indirectly relates, and overlaps with the factor "need to escape a negative situation.” This was a factor in Scheinberg and MacMillan's (1988) study. This factor refers to people being motivated by the need to move away from a negative situation. The situation could either be an unpleasant job, or an uncertain job, which might not exist in the near future. Thus, this factor relates to a previous job, or to giving the family more security in the future.

\section{DISCUSSION}

The need for independence was a motivation factor for entrepreneurs. Referring to Table 2, the need for independence was seen as one of the six factors and had three items load onto it. Looking at Table 4 illustrates that being financially independent was a strong motivation factor. Thus $\mathrm{H}_{1}$ is confirmed.

The need for material incentives was a motivation factor for entrepreneurs. This factor is supported by the data in Tables 2 and 4, which clearly show that entrepreneurs saw money as a strong motivation factor. Thus $\mathrm{H}_{2}$ is confirmed.

The need to escape a negative situation was a motivation factor for entrepreneurs. This hypothesis is supported by the results, shown in Tables 2 and 4, which illustrate that many of the entrepreneurs believe that having their own business will allow them to get away from their present situation. Thus, $\mathrm{H}_{3}$ is confirmed.

The need to contribute to the community was a motivation factor for entrepreneurs. Although Table 2 shows evidence of this need being a motivation factor, it was not very strongly supported. Thus, $\mathrm{H}_{4}$ is only partly confirmed.

\section{CONCLUSIONS}

The study was guided by the general aim of this research to examine motivation for entrepreneurs to start their own businesses in rural South Africa.

The aim of the empirical study was to determine dominant motivational factors for entrepreneurs. Based on research findings, it can be concluded that the most important reason for starting their own business were survival, financial independence and security, to escape a negative situation and to enable personal growth. Based on the factor analysis (Table 4), it can be concluded that the following factors are common to entrepreneurs: external approval, personal 
development, recognition, need for independence, influencing the community; and benefits and security.

The results of the study strongly support the view that the need for independence, material incentives and the need to escape a negative situation were important motivation factors. The need to contribute to the community was not as strong a motivation factor.

\section{LIMITATIONS}

Very few research studies have been conducted on African entrepreneurs, and those that have been done, have primarily focused on urban samples, where the literacy level and motivation factors are very different to rural samples. This study was conducted in the Northern Province of South Africa. The sample was selected from entrepreneurs who have been given loans from the Get Ahead Financial Services (GAFS). Therefore, this sample is possibly biased as only subjects who avail of the services of the Get Ahead Financial Services (GAFS) were utilised for the study. This limits the possibility of generalising the results to the wider population, as the sample is not representative of the general entrepreneurial population. The study focuses on motivation factors for entering into entrepreneurship and is therefore limited. It does not address other factors, such as the unique social and cultural factors impinging on the environment in which the entrepreneur operates. The questionnaires were in English. Due to the fact that the majority of the subjects are not English speaking, it was decided to use indigenous interviewers. Graduate students, who were bilingual and who would be accepted and trusted by the subjects were trained as interviewers.

\section{RECOMMENDATIONS}

It is recommended that an extended qualitative empirical study should consider the following aspects: Firstly, the use of a questionnaire and interview schedule in the respondent's home language, in order to avoid translation problems. The other option would be to train different interviewers from different language groups. This would enable one to conduct research on different ethnic and language groups. Secondly, in order to enrich the scope of future studies, techniques such as participant observation, focus groups and longitudinal studies should be used, to allow one to fully understand all the factors that influence the motivation of entrepreneurs.

With reference to the results of the empirical study, the following recommendations are made to the GAFS. Firstly, although GAFS supports 
entrepreneurs financially, there is a lack of other forms of support. Entrepreneurs need ongoing support and training, in order for them to survive in their business and to allow them to grow the business. Secondly, the major problems entrepreneurs encounter in starting their own businesses are related to financial issues. Therefore, there is a strong need for GAFS, or another support agency, to assist and train clients around the subject of budgeting, costing and maintaining a cash flow for the business. Thirdly, there need to be on-site visits and follow-up of GAFS to the entrepreneurs. GAFS employees would then be able to see for themselves how entrepreneurs operate, and give advice where it is needed. Fourthly, there is a need for a deeper understanding of entrepreneurs' motivation, values and perceptions of their environment, which would greatly enhance the effectiveness of policy and programme development and outcomes.

\section{REFERENCES}

1 BABBIE, E. (1998) The Practice of Social Research ( $8^{\text {th }}$ ed.) Wadsworth: London.

2 BUTTNER, E.H. \& MOORE, D.P. (1997) “Women's organizational exodus to entrepreneurship: Self-reported motivations and correlates with success”, Journal of Small Business Management, 35(1): 34-46.

3 CROMIE, S. (1987) "Motivations of aspiring male and female entrepreneurs", Journal of Occupational Behaviour, 8: 251-61.

4 DIA, M. (1991) "Development and cultural values in Sub-Saharan Africa”, Finance and Development, 12: 10-13.

5 DUBINI, P. (1988) "The influence of motivations and environments on business start-ups: Some hints for public policies”, Journal of Business Venturing, 4(1): 11-26.

6 FISCHER, E.M., REUBER, A.R. \& DYKE, L.S. (1993) "A theoretical overview and extension of research on sex, gender, and entrepreneurship", Journal of Business Venturing, 8(2): 151-68.

7 GOFFEE, R. and SCASE, R. (1985) Women in Charge, Allen \& Unwin: London.

8 HARPER, M. (1991) "Enterprise development in poorer nations", Entrepreneurship Theory and Practice, 15(4): 7-11.

9 HISRICH, R.D. \& BRUSH, C. (1984) "The women entrepreneur: Management skills and business problems”, Journal of Small Business Management, 22(1): 30-37.

10 HISRICH, R.D. \& BRUSH, C. (1985) "Women and minority entrepreneurs: a comparative analysis", in Ronstadt, R., Hornaday, J.A., Peterson, R. \& Vesper, K.S. (eds.) Frontiers of Entrepreneurship Research: 57-81, Babson College: Wellesley, Massachusetts.

11 HISRICH, R.D. (1986). "The woman entrepreneur: characteristics, skills, 
problems and prescriptions for success”, in Sexton, D.L. \& Smilor, R.W. (eds.) The Art and Science of Entrepreneurship, Ballinger, Cambridge: 61-81.

12 HOFSTEDE, G. (1980) "Motivation, leadership and organization”, Organizational Dynamics, 9(1): 42-63.

13 IHEDURU, O.C. (1998) "Black entrepreneurs in post-Apartheid South Africa”, in Spring, A. \& McDade, B.E. (eds.) African Entrepreneurship: Theory and Reality, University of Florida Press: Gainesville.

14 KUIPER, M. (1993) "Women Entrepreneurs in Africa”, Discussion Paper, No. 68, International Labour Office: Geneva.

15 KURATKO, D.F. \& HODGETTS, R.M. (1995) Entrepreneurship: A Contemporary Approach, Dryden Press: Fort Worth.

16 LEKOTA, J. (1995) "The role of SMEs in economic development in South Africa”, Development Southern Africa, 12(1): 11-13.

17 LOMBARD, J.A. \& VOSLOO, W.B. (1994) "Perspectives on the interaction between entrepreneurship and economic growth", in Vosloo, W.B. (ed.) Entrepreneurship and Economic Growth: 5-20, HSRC: Pretoria.

18 MAASDORP, G.G. (1994) "Regional development and economic growth", in Vosloo, W.B. (ed.) Entrepreneurship and Economic Growth: 345-54, HSRC: Pretoria.

19 SCHEINBERG, S. \& MACMILLAN, I.C. (1988) “An 11 country study of motivations to start a business", in R. Ronstadt, J.A. Hornaday, R. Peterson, \& K.S. Vesper (eds.) Frontiers of Entrepreneurship Research: 669-87, Babson College: Wellesley, Massachusetts.

20 SHANE, S., KOLVEREID, L. \& WESTHEAD, P. (1991) “An exploratory examination of the reasons leading to new firm formation across country and gender”, Journal of Business Venturing, 6(6): 431-46.

21 SHAPERO, A. (1975) "The displaced uncomfortable entrepreneur", Psychology Today, 9: 83-88.

22 SHAPERO, A. \& SOKOL, L. (1982) "The social dimension of entrepreneurship”, in Kent, C.A., Sexton, D.L. \& Vesper, K.H. (eds.) Encyclopaedia of Entrepreneurship: 72-90, Prentice-Hall: Englewood Cliffs.

23 SINGH, K.P. (1993) "Women entrepreneurs: their profile and motivation", The Journal of Entrepreneurship, 2(1): 47-57.

24 SPSS, INC. (1990) SPSS Advanced Statistics Guide (4 ${ }^{\text {th }}$ ed.) SPSS: Chicago.

25 SPSS (1999) SPSS base 9.0 user's guide, SPSS: Chicago.

26 THOMAS, W.H. (1994) "Promoting entrepreneurship among black South Africans", in Vosloo, W.B. (ed.) Entrepreneurship and Economic Growth: 373-83, HSRC: Pretoria. 
27 TOSTERUD, R.J. (1996) "Rural entrepreneurship. Measuring the magnitude of the challenge", Indicator SA, 13(2): 35-39.

28 VECIANA, J.M. (1999) "Entrepreneurship as a scientific research programme", Revista Europea de Direccion y Economia de la Empresa, 8(3): 1-28.

29 VIJAYA, V. \& KAMALANABHAN, T.J. (1998) "A scale to assess entrepreneurial motivation”, The Journal of Entrepreneurship, 7(2): 18398.

30 VOSLOO, W.B. (1994) “The African experience”, in Vosloo, W.B. (ed.) Entrepreneurship and Economic Growth: 109-27, HSRC, Pretoria.

31 WILKEN, P. (1979) Entrepreneurship: A Comparative and Historical Study, Ablex: New York. 